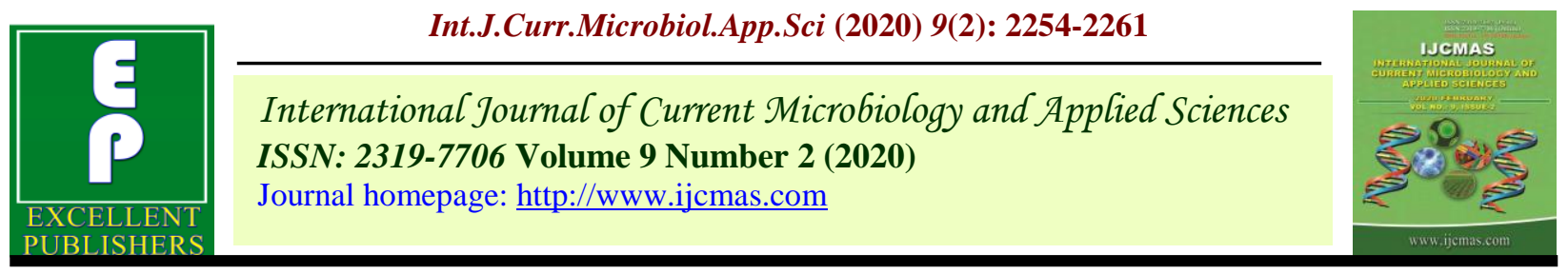

Original Research Article

https://doi.org/10.20546/ijcmas.2020.902.255

\title{
Isolation and Characterization of Plant Growth Promoting Rhizobacteria from Northern Karnataka, India
}

\author{
M. Chiranjeevi ${ }^{1 *}$, Geeta Goudar ${ }^{2}$, P. U. Krishnaraj ${ }^{2}$ and M. M. Jamadar ${ }^{3}$ \\ ${ }^{1}$ Department of Agricultural Microbiology, College of Agriculture, Vijayapur, India \\ ${ }^{2}$ Department of Agricultural Microbiology, College of Agriculture, Dharwad, India \\ ${ }^{3}$ Department of Plant Pathology, College of Agriculture, Vijayapur \\ University of Agricultural Sciences, Dharwad-580005, Karnataka, India \\ *Corresponding author
}

Keywords

PGPR, IAA, GA, Psolubilizers

Article Info

Accepted:

15 January 2020

Available Online:

10 February 2020

\section{A B S T R A C T}

An attempt was made to isolate and characterize rhizobacteria from rhizosphere soils of different crops grown in Vijayapur, Kalaburgi and Bagalkot districts of Northern Karnataka. Ten PGPR isolates and reference strain were subjected for functional characterization viz., IAA and GA production, $\mathrm{P}$ and $\mathrm{Zn}$ solubilization. Among the ten native rhizobacterial isolates, 8 isolates and reference strain produced IAA and GA. The amount of IAA and GA produced by the different rhizobacterial isolates ranged from 10.78 to $20.17 \mu \mathrm{g} / \mathrm{ml}$ of broth and 0.36 to 2.69 $\mu \mathrm{g} / \mathrm{ml}$ of broth respectively. The diameter of $\mathrm{P}$ and $\mathrm{Zn}$ solubilization by the rhizobacterial isolates ranged from 3 to $7.5 \mathrm{~mm}$ and 2.0 to $6.0 \mathrm{~mm}$ after five days of inoculation respectively. These isolates were further subjected for morphological and biochemical characterization. The isolates exhibited wide variations with respect to colony morphology. Except one isolate (PG-189), other isolates found to have rod shaped cells. Except PG-152 and PG-186, other isolates and reference strain were found to be gram negative. Endospore formation was observed only in the isolate PG-152. With respect to biochemical characterization, all the isolates and reference strain were positive for oxidase and ammonia production tests and negative for indole production and lactose fermentation.

\section{Introduction}

Plant growth promoting rhizobacteria (PGPR) are a group of heterogenous bacteria that colonize the plant roots and promote growth of plants. The term PGPR was first used by Kloepper and Schroth (1978) for the microorganisms closely associated with the rhizosphere region. It is well established that, in the rhizosphere, only $2-5 \%$ of bacteria promote plant growth (Antoun and Kloepper, 2001). The rhizosphere is a microbial hot-spot for microbial interactions due to the exudates released by plant roots, which constitute the 
main food source for microorganisms, leading to efficient geochemical cycling of nutrients.

PGPRs have a positive impact on crop development, either directly or indirectly. PGPR's direct promotion of plant growth entails either supplying the plant with a bacterium-synthesized compound, such as plant growth regulators, or promoting the environmental uptake of certain nutrients (Glick, 1995). The Indirect plant growth promotion happens when PGPR prevents one or more phytopathogenic organisms from having deleterious impacts. This can occur through the production of antagonistic substances or through the induction of pathogen resistance (Glick, 1995).By using one or more of these mechanisms, a specific PGPR may influence crop growth and development. PGPR, as biocontrol agents, may behave through multiple processes, irrespective of their role in promoting immediate development, such as manufacturing of auxin phytohormone, reduction of crop ethylene concentrations (Glick, 2012) or root-related nitrogen fixation (Dobereiner, 1992). PGPR and their interactions with plants are exploited commercially and hold great promise for sustainable agriculture.

The excessive use of synthetic fertilizers has contributed not only soil health degradation, but also many major environmental issues, such as soil and water contamination and other health-related problems besides increasing the input cost for crop production especially on the marginal farmers (Gupta et $a l .$, 2015). This situation emphasized the need for developing alternate production systems that are ecofriendly to the environment and is more judicious in maintaining soil health. One of the ecofriendly, alternate to chemical fertilizer is the use of biofertilizers. Thus, in the present study attempts have been made to screen efficient plant growth promoting rhizobacteria from northern regions of Karnataka.

\section{Materials and Methods}

\section{Collection of rhizosphere soil samples and isolation of rhizobacteria}

Rhizosphere soil samples were collected from predominant crops viz., pigeon pea, maize, chickpea, banana etc. and placed in sterile polyethylene covers, labelled and bought to the laboratory for the isolation of rhizobacteria.

Rhizobacteria were isolated from the soil samples following serial dilution and plating technique using nutrient agar and Tryptic soya agar media. The typical bacterial colonies were selected and purified by four way streaking. The isolated colonies were transferred to nutrient agar slants and used for the study.

\section{Functional characterization}

Ten rhizobacterial isolates viz., PG-145, PG148, PG-152, PG-165, PG-178, PG-180, PG185, PG-186, PG-189 and PG-197 were subjected for functional characteristics viz., IAA and GA production, $\mathrm{P}$ and $\mathrm{Zn}$ solubilization.

\section{IAA production}

Luria Bertani broth amended with $50 \mu \mathrm{g} / \mathrm{ml}$ tryptophan was inoculated with $1 \mathrm{ml}$ of overnight grown culture of the isolates and incubated at $28^{\circ} \mathrm{C}$ for $24 \mathrm{~h}$ on rotary shaker. Culture broth was centrifuged at $10,000 \mathrm{rpm}$ for 15 minutes and $4 \mathrm{ml}$ of supernatant was taken in a test tube and 2 to 3 drops of orthophosphoric acid was added. To this mixture, $2 \mathrm{ml}$ of Salkowski's reagent was added and incubated for 30minutes at room temperature until the development of pink 
colour (Gordon and Webber, 1951). The pink colour developed solution was read at $535 \mathrm{~nm}$ in a spectrophotometer.

\section{GA production}

Twenty five $\mathrm{ml}$ of the fresh culture supernatant was taken in a test tube to which two $\mathrm{ml}$ of zinc acetate was added. After two minutes, two $\mathrm{ml}$ of potassium ferrocyanide was added and centrifuged at $1000 \mathrm{rpm}$ for 15 minutes. To five $\mathrm{ml}$ of this supernatant, five $\mathrm{ml}$ of 30 per cent hydrochloric acid was added and incubated at $20^{\circ} \mathrm{C}$ for $75 \mathrm{~min}$. The blank sample was treated with 5 per cent $\mathrm{HCl}$. The absorbance of the samples as well as blank was measured at $254 \mathrm{~nm}$ in an UV-Vis spectrophotometer (Paleg, 1965). The amount of GA present in the extract was calculated from the standard curve and expressed as $\mu \mathrm{g} / \mathrm{ml}$ of the medium.

\section{Phosphate solubilizing ability of the isolates}

The ability of the test isolates to solubilize insoluble inorganic phosphate was tested by spotting $10 \mu \mathrm{l}$ of overnight grown cultures on Pikovskaya's agar plates and incubating at $28 \pm 2^{\circ} \mathrm{C}$ for $2-3$ days.

The isolates which showed clear zone of solubilization of tricalcium phosphate (TCP) around the colony were noted as phosphate solubilizers. The diameter of the zone of TCP solubilization was measured and expressed in $\mathrm{mm}$.

\section{Zinc solublizationability of the isolates}

The isolates were tested for their ability to solubilize insoluble inorganic zinc using mineral salt agar medium supplemented with $\mathrm{ZnO}(0.25 \%)$. Ten $\mu \mathrm{l}$ of overnight grown culture of test isolates were spotted on the solid medium. The isolates showing clear zone around the colony on the medium was considered as zinc solubilizers. The diameter of the zone of solubilization was measured and expressed in $\mathrm{mm}$.

\section{Characterization of the isolates}

The isolates were studied for their colony and cell morphology as per the standard procedure given by Barthalomew and Mittewar (1950). The isolates were subjected to biochemical characterization by employing the standard procedures given by Cappuccino and Sherman (1992). Different biochemical tests performed were Starch Hydrolysis, Casein hydrolysis, Gelatin hydrolysis, Production of ammonia, Lactose fermentation, Nitrate reduction, Citrate utilization, Catalase test, Ureases and Oxidase test.

\section{Results and Discussion}

\section{Isolation of Rhizobacteria}

Rhizobacterial isolates were obtained from rhizospheric soil samples collected from Vijayapur, Bagalkot and Kalaburgi districts of northern Karnataka. They were designed as PG-145, PG-148, PG-152, PG-165, PG-178, PG-180, PG-185, PG-186, PG-189 and PG197. The details of the sample and sampling locations are furnished in Table1.

\section{IAA and GA production}

Among the ten native rhizobacterial isolates, 8 isolates and reference strain produced IAA and GA.The amount of IAA produced by the different rhizobacterial isolates ranged from 10.78 to $20.17 \mu \mathrm{g} / \mathrm{ml}$ of broth. The reference strain (Pseudomonas fluorescens) recorded significantly higher IAA production of 20.17 $\mu \mathrm{g} / \mathrm{ml}$ broth. Among the native isolates, PG152 showed highest IAA production of 18.49 $\mu \mathrm{g} / \mathrm{ml}$ followed by PG-197(17.26 $\mu \mathrm{g} / \mathrm{ml})$.It is reported that eighty per cent of microorganisms isolated from the rhizosphere 
of different crops are able to synthesize and release auxins as secondary metabolites (Patten and Glick, 1996). The results of present study are also in line with the findings of Goudar et al., (2018) and Priyanka et al., (2019) who observed IAA production in rhizobacterial isolates.

Gibberellic acid is a type of phytohormone most commonly associated with modifying plant morphology by the extension of plant tissue, particularly the stem tissue (Salisbury, 1994). The amount of GA produced by the isolates ranged from 0.36 to $2.69 \mu \mathrm{g} / \mathrm{ml}$ of broth. The test isolate PG-197 showed highest GA production of $2.14 \mu \mathrm{g} / \mathrm{ml}$, followed by PG-152 $(2.04 \mu \mathrm{g} / \mathrm{ml})$. The reference (Pseudomonas fluorescens) recorded highest GA production of about $2.69 \mu \mathrm{g} / \mathrm{ml}$. These results are in agreement with the findings of Priyanka et al., (2017) who reported that the amount of GA production by different Fluorescent Pseudomonad isolates ranged from 0.56 to $18.52 \mu \mathrm{g} / 25 \mathrm{ml}$ of broth.

\section{Zinc solubilization by native rhizobacterial isolates}

The diameter of zinc solubilization by rhizobacterial isolates ranged from 2.0 to 6.0 $\mathrm{mm}$ after five days of inoculation. The maximum diameter of zone of solublization of $6.0 \mathrm{~mm}$ was reported by the isolate PG-152 which was more than the reference strain (Pseudomonas fluorescens) (3.0mm). Other isolates viz., PG-145 and PG-197 showed 5.0 and $4.0 \mathrm{~mm}$ diameter of zone of $\mathrm{Zn}$ solubilization respectively. Three $\mathrm{mm}$ diameter of zone of $\mathrm{Zn}$ solubilization was recorded by two of the isolates viz., PG-148 and PG-178.Other three isolates viz., PG-165, PG-180 and PG-185 recorded 2mm diameter of zone of $\mathrm{Zn}$ solubilization. Bacteria have the capacity to solubilize insoluble source of zinc $(\mathrm{ZnO})$ by the release of organic acids like caffeic acid, chlorggenic acid, ferulic acid, cinnamicacid, syrirgic acid and gallic acid (Hussain et al., 2015).

\section{P solubilization by native rhizobacteria}

The diameter of zone of tricalcium phosphate solubilization by the rhizobacterial isolates ranged from 3 to $7.5 \mathrm{~mm}$ after five days of inoculation. The highest diameter of zone of P- solubilization of $7.5 \mathrm{~mm}$ was recorded by the native isolate PG-197 followed by PG-178 strain $(7.0 \mathrm{~mm})$. Reference strain recorded 6.5 $\mathrm{mm}$ diameter of zone of P- solubilization. In other isolates viz., PG-148, PG-152, PG-189 and PG-145 the diameter of zone of solubilization was $6.0,6.2,4.0$ and $3.0 \mathrm{~mm}$ respectively. In general, phosphate solubilizing property is due to a drop in $\mathrm{pH}$, which has been associated with the secretion of low molecular weight organic acids such as gluconic, 2-ketogluconic, oxalic, citric, acetic, malic, and succinic acids (Zaidi et al., 2009). Mineralization of inorganic phosphate also occurs through the synthesis of a variety of different phosphatases, catalyzing the hydrolysis of phosphoric esters.

\section{Morphological and Biochemical characterization of native rhizobacterial isolates}

The isolates viz., PG-145, PG-148, PG-152, PG-165, PG-178, PG-180, PG-185, PG-186, PG-189 and PG-197 processing multifunctional activities were further subjected for morphological and biochemical characterization.

With respect to the colony morphology, three of the isolates viz., PG-145, PG-148, PG-185 and reference strain (Pseudomonas fluorescens) formed circular while other formed irregular shaped colony. Colour of the colony was transparent in case of PG-165, PG-185 and yellowish in case of PG-178 and PG-197. Creamy white coloured colony was 
formed by the other isolate PG-148 and reference strain (Pseudomonas fluorescens). The elevation of the colony was raised in case of PG-145, PG-165 and PG-186 whereas flat in case of PG-148, PG-152, PG-180, PG-185, PG-189 and also reference strain. Convex elevation of colony was observed in PG-178 and PG-197. Colony consistency was smooth in case of PG-148, PG-178 and PG197. Whereas it was dry in case of PG-145, PG-152, PG-180, as well as reference strain. Undulated colony margin was observed in PG-145, PG-152, PG-165 and PG-185 where as it was entire in case of PG-148, PG-178, PG-197, PG-80, PG-186, PG-189 and also in reference strain (Pseudomonas fluorescens). With respect to cell morphology, except one (PG-189) isolate, all the cells were found to be rod shaped. Except PG-152 and PG-186, other isolates and reference strain were gram negative. Endospore formation was observed only in PG-152.The results are in conformity with the findings of Karnwal (2017) who isolated five rhizobacteria from maize rhizosphere and subjected them for morphological characterization. The isolates were rod-shaped. Out of five isolates, four were Gram-negative while one was Grampositive (AK38). The isolate AK38 was endospore former and oxidase negative. While the other four isolates were endospore negative and oxidase positive. One of the bacteria isolated from potato rhizosphere was found to be rod shaped, motile and gram negative bacteria, which was further identified as Enterobacter cloacae (Verma and Shahi, 2015).

Table.1 Details of sampling site and samples collected for the isolation of rhizobacteria

\begin{tabular}{|c|c|c|c|c|c|c|c|c|}
\hline \multirow{2}{*}{$\begin{array}{l}\text { Sl. } \\
\text { No } \\
\text {. }\end{array}$} & \multirow[t]{2}{*}{ Place } & \multirow[b]{2}{*}{ District } & \multirow{2}{*}{$\begin{array}{l}\text { Soil } \\
\text { type }\end{array}$} & \multirow[t]{2}{*}{ Crop } & \multicolumn{3}{|c|}{ GPS values } & \multirow{2}{*}{$\begin{array}{c}\text { Code of } \\
\text { the } \\
\text { isolates }\end{array}$} \\
\hline & & & & & $\begin{array}{l}\text { Latitude } \\
\text { (N) }\end{array}$ & $\begin{array}{c}\text { Longitude } \\
\text { (E) }\end{array}$ & $\begin{array}{c}\text { Elevation } \\
\text { (m) }\end{array}$ & \\
\hline 1 & Kannur & Vijayapur & $\begin{array}{c}\text { Black } \\
\text { soil }\end{array}$ & Maize & $17^{0} 02^{\prime} 960^{\prime \prime}$ & $75^{0} 41^{\prime} 946^{\prime \prime}$ & 577 & PG-145 \\
\hline 2 & Inchageri & Vijayapur & Red soil & Pigeon pea & $17^{0} 25^{\prime} 978^{\prime \prime}$ & $75^{0} 23^{\prime} 874^{\prime \prime}$ & 538 & PG-148 \\
\hline 3 & Lamanatanda & Vijayapur & $\begin{array}{c}\text { Black } \\
\text { soil }\end{array}$ & Pigeon pea & $17^{0} 26^{\prime} 775^{\prime \prime}$ & $75^{0} 29^{\prime} 211^{\prime \prime}$ & 557 & PG-152 \\
\hline 4 & Jigaievani & Vijayapur & $\begin{array}{c}\text { Black } \\
\text { soil }\end{array}$ & Maize & $17^{0} 44^{\prime} 395^{\prime \prime}$ & $75^{0} 37^{\prime} 191^{\prime \prime}$ & 575 & PG-165 \\
\hline 5 & Hadalsang & Vijayapur & $\begin{array}{c}\text { Black } \\
\text { soil }\end{array}$ & Grape & $17^{0} 53^{\prime} 108^{\prime \prime}$ & $75^{0} 50^{\prime} 467^{\prime \prime}$ & 504 & PG-179 \\
\hline 6 & Alagudda & Kalaburgi & $\begin{array}{c}\text { Black } \\
\text { soil }\end{array}$ & Sorghum & $17^{0} 43$ "753 & $76^{0} 91$ "643 & 491 & PG-180 \\
\hline 7 & Nalvar & Kalaburgi & Red soil & Sorghum & $16^{0} 95^{\prime} 045^{\prime \prime}$ & $77^{0} 07^{\prime} 627^{\prime \prime}$ & 399 & PG-185 \\
\hline 8 & Bheemanalli & Kalaburgi & $\begin{array}{c}\text { Black } \\
\text { soil }\end{array}$ & Maize & $16^{0} 95^{\prime} 38^{\prime \prime}$ & $77^{0} 21^{\prime} 367^{\prime \prime}$ & 513 & PG-186 \\
\hline 9 & Sokanadagi & Bagalkot & $\begin{array}{c}\text { Black } \\
\text { soil }\end{array}$ & Maize & $16^{0} 23^{\prime} 409^{\prime \prime}$ & $75^{0} 56^{\prime} 645^{\prime \prime}$ & 528 & PG-189 \\
\hline 10 & Kovalli & Bagalkot & Red soil & Sorghum & $16^{0} 23^{\prime} 808^{\prime \prime}$ & $75^{0} 58^{\prime} 536^{\prime \prime}$ & 526 & PG-197 \\
\hline
\end{tabular}


Table.2 Functional characterization of native rhizobacterial isolates

\begin{tabular}{|c|c|c|c|c|c|}
\hline $\begin{array}{l}\text { Sl, } \\
\text { No. }\end{array}$ & Isolates & $\begin{array}{l}\text { Zone of P- } \\
\text { solubilization } \\
\text { (Dia in mm) }\end{array}$ & $\begin{array}{l}\text { Zone of } \mathrm{Zn-} \\
\text { solubilization } \\
\text { (Dia in mm) }\end{array}$ & $\begin{array}{c}{\text { IAA }\left(\mu \mathrm{gml}^{-1}\right.}^{\text {broth })}\end{array}$ & $\begin{array}{c}\text { GA }\left(\mu \mathbf{g ~ m l}^{-1}\right. \\
\text { broth })\end{array}$ \\
\hline 1 & PG-145 & 3.0 & 5.0 & 12.00 & 0.42 \\
\hline 2 & PG-148 & 6.0 & 3.0 & 13.81 & 1.07 \\
\hline 3 & PG-152 & 6.2 & 6.0 & 18.49 & 2.04 \\
\hline 4 & PG-165 & - & 2.0 & - & - \\
\hline 5 & PG-178 & 7.0 & 3.0 & 17.26 & 1.28 \\
\hline 6 & PG-180 & - & 2.0 & 13.10 & 1.03 \\
\hline 7 & PG-185 & - & 2.0 & - & - \\
\hline 8 & PG-186 & - & - & 10.78 & 0.36 \\
\hline 9 & PG-189 & 4.0 & - & 15.11 & 1.22 \\
\hline 10 & PG-197 & 7.5 & 4.0 & 16.35 & 2.14 \\
\hline 11 & $\begin{array}{l}\text { Reference strain }(P . \\
\text { fluorescens) }\end{array}$ & 6.5 & 3.0 & 20.17 & 2.69 \\
\hline \multirow{2}{*}{\multicolumn{2}{|c|}{$\begin{array}{c}\text { S.Em } \pm \\
\text { CD @ 1\% }\end{array}$}} & & & 0.24 & 0.08 \\
\hline & & & & 0.77 & 0.24 \\
\hline
\end{tabular}

Note: (-) indicates no zone of solubilization.

Table.3 Morphological characteristics of rhizobacterial isolates

\begin{tabular}{|c|c|c|c|c|c|c|c|c|c|}
\hline \multirow{2}{*}{$\begin{array}{l}\text { Sl. } \\
\text { No }\end{array}$} & \multirow{2}{*}{$\begin{array}{l}\text { Code of the } \\
\text { isolates }\end{array}$} & \multicolumn{5}{|c|}{ Colony morphology } & \multicolumn{3}{|c|}{ Cell morphology } \\
\hline & & $\begin{array}{c}\text { Colony } \\
\text { shape }\end{array}$ & Colour & Elevation & Consistency & Margin & $\begin{array}{l}\text { Endospore } \\
\text { formation }\end{array}$ & $\begin{array}{c}\text { Gram } \\
\text { reaction }\end{array}$ & $\begin{array}{c}\text { Cell } \\
\text { Shape }\end{array}$ \\
\hline 1 & PG-145 & Circular & $\begin{array}{l}\text { Creamy } \\
\text { white }\end{array}$ & Raised & Dry & Undulated & - & G-ve & Rod \\
\hline 2 & PG-148 & Circular & $\begin{array}{l}\text { Creamy } \\
\text { white }\end{array}$ & Flat & smooth & Entire & - & G-ve & Rod \\
\hline 3 & PG-152 & Irregular & $\begin{array}{l}\text { Creamy } \\
\text { white }\end{array}$ & Flat & Dry & Undulated & + & G+ve & Rod \\
\hline 4 & PG-165 & Irregular & Transparent & Raised & Smooth & Undulated & - & G-ve & Rod \\
\hline 5 & PG-178 & Irregular & Yellowish & Convex & Smooth & Entire & - & G-ve & Rod \\
\hline 6 & PG-180 & Irregular & $\begin{array}{c}\text { Creamy } \\
\text { white }\end{array}$ & Flat & Dry & Entire & - & G-ve & Rod \\
\hline 7 & PG-185 & Circular & Transparent & Flat & Smooth & Undulated & - & G-ve & Rod \\
\hline 8 & PG-186 & Irregular & $\begin{array}{l}\text { creamy } \\
\text { white }\end{array}$ & Raised & smooth & Entire & - & $\mathrm{G}+\mathrm{ve}$ & Rod \\
\hline 9 & PG-189 & Irregular & $\begin{array}{l}\text { creamy } \\
\text { white }\end{array}$ & Flat & smooth & Entire & - & G-ve & Cocci \\
\hline 10 & PG-197 & Irregular & Yellowish & Convex & Smooth & Entire & - & G-ve & Rod \\
\hline 11 & $\begin{array}{l}\text { Reference } \\
\text { strain }(P . \\
\text { fluorescens })\end{array}$ & Circular & $\begin{array}{l}\text { Creamy } \\
\text { white }\end{array}$ & Flat & Dry & Entire & - & G-ve & Rod \\
\hline
\end{tabular}


Table.4 Biochemical characteristics of rhizobacterial isolates

\begin{tabular}{|c|c|c|c|c|c|c|c|c|c|c|c|c|}
\hline $\begin{array}{c}\text { SI. } \\
\text { No }\end{array}$ & $\begin{array}{c}\text { Code of the } \\
\text { isolates }\end{array}$ & $\mathbf{1}$ & $\mathbf{2}$ & $\mathbf{3}$ & $\mathbf{4}$ & $\mathbf{5}$ & $\mathbf{6}$ & $\mathbf{7}$ & $\mathbf{8}$ & $\mathbf{9}$ & $\mathbf{1 0}$ & $\mathbf{1 1}$ \\
\hline $\mathbf{1}$ & PG-145 & - & - & - & + & + & + & + & + & + & + & + \\
\hline $\mathbf{2}$ & PG-148 & + & - & - & + & + & + & + & + & + & + & + \\
\hline $\mathbf{3}$ & PG-152 & + & - & - & + & + & + & + & + & + & + & + \\
\hline $\mathbf{4}$ & PG-165 & - & - & - & - & + & + & - & - & - & + & + \\
\hline $\mathbf{5}$ & PG-178 & + & - & - & + & - & + & - & - & - & + & + \\
\hline $\mathbf{6}$ & PG-180 & + & - & - & + & + & + & + & - & - & + & + \\
\hline $\mathbf{7}$ & PG-185 & + & - & - & - & + & + & + & + & + & + & + \\
\hline $\mathbf{8}$ & PG-186 & + & - & - & - & + & + & + & + & + & + & + \\
\hline $\mathbf{9}$ & PG-189 & - & - & - & + & + & + & - & - & - & + & + \\
\hline $\mathbf{1 0}$ & PG-197 & + & - & - & + & - & - & - & - & - & + & + \\
\hline $\mathbf{1 1}$ & $\begin{array}{l}\text { Reference strain } \\
\text { (P. fluorescens) }\end{array}$ & + & - & - & + & + & + & + & + & + & + & + \\
\hline
\end{tabular}

Note:

1) Starch hydrolysis 2) Indole production 3) Lactose fermentation 4) Citrate utilization

$\begin{array}{llll}\text { 5) Catalase test } & \text { 6) Casein hydrolysis 7) Gelatin hydrolysis } & 8 \text { ) Nitrate reduction }\end{array}$

9) Urease test 10) Oxidase 11) Ammonia production

+: Positive, -: Negative

All the isolates and reference strain were positive for oxidase and ammonia production tests and negative for indole production and lactose fermentation. Except PG-145, PG165, PG-189,other isolates and reference strain (Pseudomonas fluorescens) showed positive for starch hydrolysis. Except PG-165, PG-185 and PG-186, other isolates and reference strain showed positive for citrate utilization. Except PG-178 and PG-197, other isolates and reference strains (Pseudomonas fluorescens) were positive for casein hydrolysis. Except four isolates (PG-178, PG165, PG-189 and PG-197), other isolates and reference strain showed positive for gelatine hydrolysis. The present work is supported by the findings of Rana et al., (2011) who reported that the isolates obtained from the rhizosphere soil of wheat were found to be positive for nitrate reduction, casein hydrolysis and citrate utilization. Whereas, the isolates PG-165, PG-178, PG-180 and PG-197 showed negative for nitrate reductase and urease test.

In conclusion, indiscriminate use of chemical fertilizer and pesticides over the last few decades has not only resulted in the contamination of environment, but also reduced the soil fertility in general and soil microbial population in particular. The use of PGPR inoculants as biofertilizers is a competent approach to replace chemical fertilizers and pesticides for sustainable agriculture in India. The present study resulted in obtaining efficient rhizobacterial isolates with multifunctional properties. These isolates can be developed as a biofertilizers after conducting appropriate field trials

\section{References}

Antoun, H. and Kloepper, J. W. 2001. Plant growth-promoting rhizobacteria (PGPR) In: Brenner, S. \& Miller, J. H. (eds.)Encyclopaedia of Genetics. Academic Press, NewYork, pp. 1477-1480.

Barthalomew, J. W. and Mittewer, J. 1950. A simplified bacterial strain. Stain Tech., 25: 153.

Beneduzi, A., Peres, D., Vargas, L. K., BodaneseZanettini, M. H. and Passaglia, L. M. P. 2008 Evaluation of genetic diversity and 
plant growth promoting activities of nitrogen-fixing bacilli isolated from rice fields in South Brazil. Appl. Soil Ecol., 39(3):311-320.

Cappuccino, J. G. and Sherman, N. 1992. Microbiology: A Laboratory Manual, The Benjamin/Comings Publishing Company, Inc., California.

Dobereiner, J. 1992. History and new perspectives of diazotrophs in association with nonleguminous plants. Symbiosis, 13: 1-13.

Glick, B. R. 1995. The enhancement of plant growth by free-living bacteria. Can. J. Microbiol.,41:109-117.

Glick, B. R. 2012. Plant growth-promoting bacteria: mechanisms and applications. Scientifica,1-15.

Gordon, A. S. and Weber, R. P. 1951. Colorimetric estimation of indole acetic acid. Plant Physiology, 26(1): 192-195.

Goudar, G., Sreenivasulu, G. and Krishnaraj, P. U. 2018. Evaluation of Bacillus Strains Isolated from Doni River Belt of Vijayapura District for their Plant Growth Promotional Activity. Int. J. Curr. Microbiol. App. Sci., 7(12): 628-639.

Hussain, A., Muhammad. A., Zahi. A. and Asghar. M. 2015. Prospects of zinc solubilizing bacteria for enhancing growth of maize. Pak. J. Agri. Sci., 52(4): 915-922.

Karnwal, A. 2017. Isolation and identification of plant growth promoting rhizobacteria from maize (Zea mays L.) rhizosphere and their plant growth promoting effect on rice (Oryzasativa L.). J. Pl. Prot. Res., 57(2): 144-151.

Klopper, J. W. and Schroth, M. N. 1978. Plant growth promoting rhizobacteria on radishes. In:Proceeding IV International
Conference on Plant Pathogenic Bacteria, Angers, France, pp. 879-882

Paleg, L. G.,1965. Physiological effects of gibberellins. Annu. Rev. Pl. Physiol., 16: 291-322.

Patten, C. L. and Glick, B. R. 1996. Bacterial biosynthesis of indole-3-acetic acid. Can. J. Microbiol., 42: 207-220.

Priyanka., Goudar, G., Jones Nirmalnath, P. and Patil, P. V. 2017. Isolation, characterization and antagonistic activity of fluorescent Pseudomonads. Int. J. Curr. Microbiol. App. Sci., 6(12): 3883-3898.

Priyanka. and Goudar, G. 2019. In-vitro screening of fluorescent pseudomonads against Colletotrichumtruncatumof soybean (Glycine max L. Merrill). Journal of Pharmacognosy and Phytochemistry, 8(6): 115-118.

Rana, A., Saharan, B., Nain, L., Prasanna, R. and Shivay. Y. S. 2012. Enhancing micronutrient uptake and yield of wheat through bacterial PGPR consortia. Soil Sci. Pl. Nutr.,58(2):572-582.

Salisbury, F. B. 1994. The role of plant hormones in plant environment interactions. (Eds) Wilkinson, R. K., Marcel Dekker, New York, USA, pp. 39-81.

Verma, P. and Shahi, S. K. 2015. Isolation and characterization of bacterial isolates from potatorhizosphere as potent plant growth promoters, Int. J. Curr.Microbiol. App. Sci., 4(3): 521-528.

Zaidi, A., Khan, M. S., Ahemad, M. and Oves, M. 2009. Plant growth promotion by phosphate solubilizing bacteria.Acta.Microbiol.Immunol. Hung. 56: $263-284$.

\section{How to cite this article:}

Chiranjeevi, M., Geeta Goudar, P. U. Krishnaraj and Jamadar, M. M. 2020. Isolation and Characterization of Plant Growth Promoting Rhizobacteria from Northern Karnataka, India. Int.J.Curr.Microbiol.App.Sci. 9(02): 2254-2261. doi: https://doi.org/10.20546/ijcmas.2020.902.255 